\title{
Pembibitan Ternak Sapi Potong dalam Sistem Integrasi Tanaman - Ternak di Kawasan Pantai Selatan Kabupaten Bantul
}

\author{
Soeharsono, Sinung Rustijarno dan Kurnianita Triwidyastuti \\ Balai Pengkajian Teknologi Pertanian Yogyakarta
}

\begin{abstract}
INTISARI
Penelitian ini bertujuan untuk mengetahui menejemen usaha pembibitan ternak sapi potong dalam sistem integrasi tanaman-ternak di kawasan pantai selatan Kabupaten Bantul Daerah Istimewa Yogyakarta. Farm record keeping dilakukan pada kelompok tani ternak sapi potong Andini Mukti Desa Poncosari Kec. Srandakan Kab. Bantul. Sejumlah 20 petani dikelompokkan sesuai dengan sistem usahatani: 1) Sistem usaha pembibitan ternak sapi potong dan 2) Sistem usahatani integrasi usahatani padi - ternak sapi potong. Menejemen usahatani dan ternak dicatat dan ditabulasi. Data dianalisis dengan distribusi frekuensi dan diskripsi. Hasil penelitian menunjukkan bahwa sistem usaha pembibitan ternak sapi potong dengan kepemilikan rata-rata 2,36 ekor induk sapi/peternak. Ternak dipelihara dalam kawasan kandang kelompok secara individu dengan pakan berupa jerami padi yang diberikan secara ad libitum ditambah konsentrat rata-rata $1,5 \mathrm{~kg} / \mathrm{ekor}$. Sistem perkawinan dilakukan dengan inseminasi buatan dengan tingkat service/conception (S/C) 2,39. Curahan tenaga kerja dalam pengelolaan ternak 114,06 HOK/peternak/tahun. Hasil usaha berupa pedet sapi potong dan pupuk organik. Pendapatan pada usaha pembibitan ternak sapi potong sebesar Rp 3.013.000 (R/C 1,64). Sistem usahatani integrasi padi - ternak sapi potong dengan pola tanam padi - padi - palawija. Kepemilikan lahan $1000 \mathrm{~m}^{2} /$ peternak dengan 2 ekor induk sapi potong yang dipelihara di kawasan kandang kelompok. Penggunaan sarana produksi berupa bibit 45,83 kg/ha; pupuk 395,52 kg/ha dan tenaga kerja keluarga 43,06 HOK dan tenaga kerja luar keluarga 15,03 HOK setiap musim tanam. Produktivitas lahan gabah kering panen 6,88 ton/ha. Pendapatan usahatani integrasi padi-ternak sapi potong rata-rata sebesar Rp 5.592.310 (R/C 1,82).
\end{abstract}

Kata Kunci : pengelolaan, pembibitan, sapi potong, integrasi

\section{Beef Cattle Breeding in the Integrate Crop-Livestock System in South Coastal Area Bantul Regency}

\section{ABSTRACT}

This research aimed to know the management effort beef cattle breeding in the integrate crop - livestock system in south coastal area Bantul regency of Yogyakarta Special Region. Farm Record keeping conducted livestock farmer group Andini Mukti of Poncosari village, Srandakan countryside, Bantul regency. A number of 20 farmers grouped by as according to farming system : 1) Beef cattle breeding farming system and 2) Integrate rice crop-livestock system. Management farming and livestock noted and tabulation. Data analysed with the distribution frequency and discription. This results of research indicate that the beef cattle breeding system by ownership 2,36 cows/farmer. Beef cattle looked in group individually cage area. Hay from weste rice crop given ad libitum added consentrate mean $1,5 \mathrm{~kg} / \mathrm{head}$. Insemination system conducted with the artificial insemination made in 
with the $S / C$ 2,39. Labour effusing in livestock management 114,06 work day person/farmerlyear. This result of effort in the calf and organic fertilizer. Effort income beef cattle breeding system equal Rp 3.013.000 (R/C 1,64). Integrate rice crop - livestock with the pattern plant the paddy - paddy-crops planted. Farm ownership $1000 \mathrm{~m}^{2} /$ farmers and 2 cows which looked in cage group area. Using produce in the form of seed 45,83 kg/ha; fertilize 395,52 kg/ha and family labour 43,06 work day person and external labour 15,03 work day person every season plant. The productivity of unhulled paddy dry harvest 6,88 ton/ha. Income farming system integrate rice crop - livestock equal to Rp 5.592.310 ( $R / C$ $1,82)$.

Key words : management, breeding, beef cattle, integration

\section{PENDAHULUAN}

Kebutuhan masyarakat akan produk peternakan akan terus meningkat seiring dengan pesatnya pertambahan jumlah penduduk, perbaikan kesejahteraan dan adanya perubahan gaya hidup masyarakat. Produk peternakan khususnya daging yang berasal sapi potong tidak mampu untuk memenuhi kebutuhan masyarakat, sehingga diprediksikan pasokan daging import semakin meningkat dan mencapai $70 \%$ pada tahun 2020 (Wiyono dan Mariyono, 2005).

Usaha cow calf operation kurang diminati oleh pemodal, karena diperlukan modal usaha yang besar, sedangkan bunga kredit tinggi, rantai pemasaran rumit, sarana transportasi dan pemilikan lahan terbatas yang akhirnya belum memberikan keuntungan ekonomis dan dibutuhkan waktu pemeliharaan yang cukup lama. Saat ini usaha peternakan untuk menghasilkan sapi bakalan 99\% dilakukan oleh peternakan rakyat. Usaha ini tetap bertahan karena merupakan usaha sambilan, memanfaatkan waktu luang, tabungan, memanfaatkan produk samping agroindustri, atau alasan lainnya, tetapi justru berdaya saing (Diwyanto et al., 2003). Kerugian tersebut tidak terjadi pada peternakan rakyat karena pemeliharaan sapi diusahakan dalam suatu sistem yang terintegrasi, sehingga biaya pakan sangat kecil. Inounu dan Lubis (2005) melaporkan bahwa ternak sapi potong merupakan hal yang tidak dapat terpisahkan dalam kehidupan rumah tangga tani. Untuk dapat berkembang ternak dan tanaman saling bersimbiosis secara mutualisme. Dalam hal ini tentunya ternak umumnya membutuhkan bagian dari tanaman untuk pakan sedangkan tanaman membutuhkan pupuk yang dapat diperoleh dari kotoran ternak untuk dapat tumbuh dan berproduksi.

Berkaitan dengan hal tersebut di atas pendekatan integrasi tanaman-ternak (crop livestock systems) sangat relevan untuk diterapkan. Pada prinsipnya konsep crop listock systems (CLS) adalah meningkatkan efisiensi usaha dengan memanfaatkan input produksi dari dalam (internal input). Petani yang selama ini hanya bertumpu pada usahatani tanaman pangan diharapkan dapat mengusahakan ternak agar memperoleh tambahan pendapatan. Pengembangan pembibitan ternak sapi potong secara terintegrasi mampu memberikan semangat dalam berwirausaha. Usaha pembibian ternak sapi potong mempunyai dinamika yang bervariasi dari waktu kewaktu.

\section{MATERI DAN METODE}

Penelitian dilakukan di kelompok tani ternak sapi potong Andini Mukti Desa Poncosari Kec. Srandakan Kab. Bantul. Sejumlah 20 petani dikelompokkan sesuai dengan sistem usahatani: 1) Sistem usaha pembibitan ternak sapi potong. Kepemilikan induk sapi potong rata-rata 2 ekor/petani. Ternak sapi potong dipelihara oleh masingmasing peternak di kawasan kandang kelompok. Pakan jerami padi diberikan ad libitum dan konsentrat sebanyak 1,5 $\mathrm{kg} / \mathrm{ekor} /$ hari. Sistem perkawinan dengan 
inseminasi buatan (IB). dan 2) Sistem usahatani integrasi usahatani padi-ternak sapi potong. Kepemiliakan lahan rata-rata $1000 \mathrm{~m}^{2}$ dengan pola tanam padi-padi palawija dan 2 ekor induk sapi potong Farm record keeping menejemen usahatani tanaman dan ternak dicatat dan ditabulasi. Data dianalisis dengan distribusi frekuensi dan diskripsi. Analisis input-output digunakan untuk mengetahui tingkat pendapatan sistem usahatani integrasi tanaman-ternak.

\section{HASIL DAN PEMBAHASAN}

\section{Karakteristrik Sumberdaya Alam}

Wilayah Kecamatan Srandakan merupakan salah satu kawasan pesisir Kab. Bantul dengan luas wilayah 1.993,60 ha, suhu rata-rata $29^{\circ} \mathrm{C}$ dengan curah hujan ratarata $1.399,6 \mathrm{~mm} /$ tahun. Kondisi tanah agak masam dengan kisaran $\mathrm{pH}$ tanah 5,35. Tingkat kepemilikan lahan pertanian ditinjau dari aspek kepadatan agraria mencapai 10 orang/ha dari tingkat Kepadatan penduduk di wilayah Kecamatan Srandakan.mencapai $1.589 \mathrm{jiwa} / \mathrm{km}^{2}$. Pola tanamnya sesuai pola curah hujan tahunan dua kali musim tanam padi dan sekali musim tanam palawija direncanakan dalam pola tanam padi-padi-palawija (BIPP Bantul, 2005).

Wilayah penelitian yang dialiri satu sungai besar di sisi timur muara Sungai Progo. Sungai Progo selain berfungsi untuk pengairan lahan pertanian, juga sangat rawan terhadap bencana banjir yang terjadi setiap tahun. Kondisi DAS Progo yang mempunyai kandungan sedimen material pasir dari gunung Merapi dimanfaatkan oleh masyarakat setempat untuk mendapatkan penghasilan melalui penambangan pasir. Ketersediaan sumberdaya tanah dan air di wilayah tersebut berpotensi untuk kegiatan pertanian. Penggunaan lahan pertanian untuk penanaman hijauan pakan yang berupa rumput raja dibudidayakan di pinggir-pinggir jalan dan dibagian pematang sawah. Potensi hijauan rumput terbesar diperoleh dari daerah pinggiran kawasan aliran sungai. Di beberapa tempat DAS Progo bagian tengah dan hilir terdapat lahan gosong atau lebih dikenal dimasyarakat DAS Progo dengan nama lahan "Wedi Kengser". Kawasan "Wedi Kengser" merupakan suatu areal material dari aliran sungai yang terletak di pinggir sungai, lahan ini sekalipun terletak di bantaran sungai namun sudah ada sejak puluhan tahun yang lalu dan tidak pernah hanyut terbawa banjir. Kawasan wedi kengser di Kec. Srandakan seluas 221,875 ha. Kawasan tersebut sebagian besar dimanfaatkan oleh masyarakat sekitar aliran sungai untuk bididaya hijauan pakan ternak dan sebagian untuk ditanami tanaman pangan. Potensi hijauan pakan ternak sebesar 222.267,75 ton/tahun yang mampu mendukung 20.023 ekor ternak sapi potong (Supriadi dan Soeharsono, 2003).

\section{Pembibitan Sapi Potong dalam Sistem Integrasi Tanaman-Ternak}

Usahatani integrasi tanaman pangansapi potong telah umum dilakukan oleh petani khususnya di Desa Poncosari Kec. Srandakan terutama didaerah agroekologi lahan sawah umumnya di kawasan pantai selatan Kab. Bantul. Petani memelihara ternak di dalam kandang kelompok, meskipun dengan manajemen pemeliharaan secara individual. Kandang kelompok ini didirikan di atas tanah milik Pemerintah Desa yang disewa oleh Kelompok Tani. Peran Pemerintah Desa didalam prakarsa untuk mewujudkan perkandangan berkelompok ini cukup positif. Pemerintah Desa menyediakan tanah kas Desa, petani menyewa lahan tersebut dan mendirikan kandang ternaknya di atas lahan tersebut. Ternak yang dipelihara di masing-masing kandang yang didirikan masing-masing petani tersebut, tetap dipelihara secara individual petani sebagai pemilik; namun manajemen perkandangan kelompok ini dilakukan oleh seluruh anggota kelompok secara bergiliran, misalnya dalam hal penjagaan keamanan, kerapian, penerangan 
(Musofie dan Wardhani, 2001). Pembangunan kandang kelompok ini akan memudahkan transfer teknologi karena komunikasi tidak perlu dilakukan dengan menemui petani satu persatu di rumahnya, melainkan cukup di lokasi kandang kelompok, sebab di salah satu bagian lokasi kandang kelompok juga tersedia satu bangunan khusus yang digunakan untuk berbagai keperluan anggota kolompok tani termasuk untuk pertemuan-pertemuan kelompok. Hal-hal yang dilakukan oleh seorang petani akan dapat dengan mudah dilihat oleh petani lainnya; sehingga diharapkan hal-hal yang baru yang kemungkinan masih dicoba-coba oleh petani akan juga dicoba-coba oleh petani yang lain. Sistem pengelolaan usahatani integrasi tanaman-ternak ditunjukkan dalam Tabel 1.

Tabel 1. Sistem Pengelolaan Usahatani Integrasi Tanaman-Ternak Sapi Potong dalam di Kelompok Ternak Andini Mukti Desa Poncosari Kecamatan Srandakan, Kabupaten Bantul

\begin{tabular}{|c|c|c|c|}
\hline \multirow{2}{*}{ No } & \multirow{2}{*}{ URAIAN } & \multicolumn{2}{|c|}{ Pengelolaan Sistem Usahatani } \\
\hline & & Sapi potong & Padi - sapi potong \\
\hline $\mathrm{I}$ & Tujuan usaha & $\begin{array}{l}\text { - Usaha pembibitan sapi } \\
\text { potong }\end{array}$ & $\begin{array}{l}\text { - Usahatani pertanian padi } \\
\text { dan pembibitan sapi potong }\end{array}$ \\
\hline II & Sarana input & & \\
\hline 1 & Investasi & $\begin{array}{l}\text { - Kandang, induk sapi } \\
\text { potong }\end{array}$ & $\begin{array}{l}\text { - Lahan, kandang, induk sapi } \\
\text { potong }\end{array}$ \\
\hline 2 & Bibit & - & - Varietas IR-64, Ciherang \\
\hline 3 & Pupuk & - & $\begin{array}{l}\text { - Pupuk komersial (urea, TSP } \\
\text { dan } \mathrm{KCl} \text { ) dan pupuk organik }\end{array}$ \\
\hline 4 & Obat-obatan & - Obat cacing (komersial) & $\begin{array}{l}\text { - Obat cacing (komersial) } \\
\text { - Obat komersial untuk hama } \\
\text { dan penyakit tanaman }\end{array}$ \\
\hline 5 & Pakan & $\begin{array}{l}\text { - Sumber serat (jerami } \\
\text { padi dan rumput) }\end{array}$ & $\begin{array}{l}\text { - Sumber serat (jerami padi } \\
\text { dan rumput) }\end{array}$ \\
\hline & & $\begin{array}{l}\text { - Konsentrat komersial } \\
\text { dan bekatul } \\
\text { - Vitamin dan mineral }\end{array}$ & $\begin{array}{l}\text { - Konsentrat komersial atau } \\
\text { bekatul } \\
\text { - Vitamin dan mineral }\end{array}$ \\
\hline 6 & Perkawinan & - Inseminasi buatan & - Inseminasi buatan \\
\hline 7 & Tenaga kerja & $\begin{array}{l}\text { - Keluarga (mencari } \\
\text { pakan, memberi pakan, } \\
\text { minum, pembersihan } \\
\text { kandang) }\end{array}$ & $\begin{array}{l}\text { - Keluarga (mengolah pakan, } \\
\text { mencari pakan, memberi } \\
\text { pakan, minum, pembersihan } \\
\text { kandang, mengolah lahan, } \\
\text { tanam, pemeliharaan, } \\
\text { pemupukan, panen) dan } \\
\text { - Non keluarga/upahan } \\
\text { (mengolah lahan, tanam dan } \\
\text { panen) }\end{array}$ \\
\hline III & Out put & $\begin{array}{l}\text { - Bakalan sapi potong } \\
\text { - Pupuk organik }\end{array}$ & $\begin{array}{l}\text { - Bakalan sapi potong } \\
\text { - Pupuk organik } \\
\text { - Beras dan } \\
\text { - Jerami padi }\end{array}$ \\
\hline
\end{tabular}

Usaha ternak sapi potong sebagai usaha sambilan dengan tujuan usaha pembibitan ternak. Setiap petani memiliki kapling lahan seluas $100 \mathrm{~m}^{2}$ yang disewa dari kas desa dalam kawasan kandang kelompok sebagai perkampungan ternak.

Sains Peternakan Vol. 6 (1), 2008 
Sistem pemeliharaan ternak sapi dilakukan secara individu yang berada di kawasan kandang kelompok. Tingkat kepemilikan ternak di kawasan kandang kelompok antara 1 sampai 4 ekor per peternak (rata-rata 2 ekor induk per peternak). Jenis sapi potong yang dipelihara terdiri dari keturunan Simental (42,67\%), Peranakan Ongole $(32,68 \%)$, dan Limosin (24,65\%). Ketersediaan fasilitas inseminasi buatan (IB) di tiap-tiap desa merupakan suatu usaha dalam perbaikan kualitas produksi. Untuk menilai efisiensi reproduksi pada ternak, salah satu cara yang dilakukan melalui penghitungan jumlah inseminasi yang dibutuhkan oleh seekor betina sampai terjadi konsepsi yang dikenal dengan istilah service per conception (S/C). Sapi-sapi induk di kelompok ternak sapi potong Andini Mukti dalam populasi $\mathrm{S} / \mathrm{C}$ rata-rata 2,39. Wiyono dan Mariyono (2005) melaporkan bahwa induk - induk sapi potong hasil silangan tingkat $\mathrm{S} / \mathrm{C}$ antara 2,2 sampai 2,8.

Pengelolaan usahatani secara terintegrasi antara tanaman pangan-ternak sapi potong. Jerami padi diperoleh dari sisa tanaman padi yang dipotong 10 sampai 15 $\mathrm{cm}$ dari permukaan tanah dinilai cukup potensial sebagai sumber hijauan pakan. Dalam usahatani padi, sebagian besar petani menggunakan varietas IR-64 sebagai varietas unggul. Perlu diketahui bahwa produksi jerami padi dapat mencapai 6,25 ton $\mathrm{BK} / \mathrm{ha} /$ panen, tergantung pada lokasi dan jenis varietas yang ditanam. Limbah pertanian dimanfaatkan sebagai sumber pakan serat untuk ternak sapi, namun demikian jerami padi sebagai pakan belum diolah secara optimal dan sistem pemberiannya pun tidak dibatasi. Disamping jerami dari usahatani padi juga dapat dihasilkan dedak padi yang potensial digunakan sebagai salah satu komponen ransum untuk ternak.

Limbah kandang yang berupa feses, urine dan sisa pakan dapat digunakan sebagai pupuk organik. Potensi limbah kandang rata-rata 6,908 ton/ekor/tahun dengan kadar air sekitar 75\%. Untuk dapat digunakan sebagai pupuk diperlukan proses dekomposisi untuk pengubahan limbah organik menjadi pupuk organik melalui aktivitas biologis pada kondisi terkontrol. Dekomposisi pada dasarnya adalah menurunkan rasio $\mathrm{C} / \mathrm{N}$ limbah organik, mematikan biji-bijian gulma dan bakteribakteri patogen serta menghasilkan suatu produk pupuk organik yang seragam. Kondisi terkontrol tersebut sangat penting agar proses dekomposisi berlangsung secara kontinyu sampai terbentuk pupuk organik yang stabil dan berkualitas baik (Haryanto et al., 2002). Untuk diolah menjadi pupuk organik kadar air limbah kandang diturunkan menjadi 50 sampai $60 \%$ dan penyusutan selama proses pembuatan pupuk organik sekitar 30 sampai $40 \%$, sehingga potensi pupuk organik yang dihasilkan oleh induk sapi rata-rata 3,109 ton/ekor/tahun. Pupuk organik tersebut dapat dimanfaatkan dalam pengelolaan usaha pertanian maupun dapat dijual.

\section{Pendapatan Usahatani Integrasi Tanaman - Ternak}

Keberadaan usahatani ternak sapi potong kelompok ternak Andini Mukti mempunyai tiga aspek fungsi yaitu: 1) fungsi produksi (penyedia bibit bakalan); dan 2) fungsi ekonomi (sebagai tabungan). Keterpaduan sistem usahatani tanaman ternak ruminansia akan mempunyai dampak terhadap perubahan ekonomi petani bila pengelolaan usahatani berorientasi pasar. Sapi yang merupakan bagian dari usahatani mempunyai peluang pasar yang sama dengan komoditas tanaman pangan. Analisis pendapatan sistem usahatani integrasi tanaman padi - ternak sapi potong ditunjukkan di dalam Tabel 2.

Curahan tenaga kerja keluarga dalam pengelolaan ternak 114,06 HOK/ peternak/tahun, waktu tersebut digunakan dalam pencarian hijauan pakan (jerami padi, dan rumput), pemberian pakan, minum dan pembersihan kandang. Hal ini menunjukkan bahwa usaha sambilan pemeliharaan ternak sapi potong dalam usaha tani integrasi tanaman-ternak merupakan pemanfaatan 
waktu luang diluar usaha tanaman. Hasil usaha berupa pedet sapi potong dan pupuk organik. Pendapatan pada usaha pembibitan ternak sapi potong sebesar Rp 3.013.000 $(\mathrm{R} / \mathrm{C} 1,64)$. Sistem usahatani integrasi padi ternak sapi potong dengan pola tanam padi padi - palawija. Kepemilikan lahan 1000 $\mathrm{m}^{2}$ /peternak dengan 2 ekor induk sapi potong yang dipelihara di kawasan kandang kelompok. Penggunaan sarana produksi berupa bibit $45,83 \mathrm{~kg} / \mathrm{ha}$; pupuk 395,52 $\mathrm{kg} / \mathrm{ha}$ dan tenaga kerja keluarga 43,06 HOK dan tenaga kerja luar keluarga 15,03 HOK setiap musim tanam. Biaya yang dikeluarkan atas tenaga kerja keluarga selama pengelolaan tanaman dan ternak merupakan biaya yang tidak riel dikeluarkan oleh petani. Produktivitas lahan gabah kering panen 6,88 ton/ha. Pendapatan usahatani integrasi padi - ternak sapi potong rata-rata sebesar Rp 5.592.310 (R/C 1,82).

Tabel 2. Analisis Pendapatan Usahatani Sistem Integrasi Padi-Ternak Sapi Potong di Desa Poncosari, Srandakan, Bantul pada Tahun 2005

\begin{tabular}{|l|r|r|}
\hline \multirow{2}{*}{ URAIAN } & \multicolumn{2}{|c|}{ Sistem Usahatani } \\
\cline { 2 - 3 } & Sapi potong & Padi - sapi potong \\
\hline BIAYA TETAP & $\mathbf{9 . 6 0 0 . 0 0 0}$ & $\mathbf{5 0 . 0 4 0 . 0 0 0}$ \\
- Lahan & - & 40.000 .000 \\
- Induk sapi potong & 7.100 .000 & 7.540 .000 \\
- Kandang & 2.500 .000 & 2.500 .000 \\
\hline BIAYA VARIABEL & $\mathbf{2 . 3 4 5 . 5 0 0}$ & $\mathbf{3 . 6 6 1 . 5 0 0}$ \\
Biaya eksplisit & 825.500 & 1.081 .500 \\
- Benih & - & 68.750 \\
- Pupuk urea, TSP dan KCl & - & 197.750 \\
- Pestisida & - & 26.000 \\
- Tenaga kerja upah & - & 250.000 \\
- Konsentrat & 547.500 & 220.000 \\
- Obat dan vitamin & 53.000 & 34.000 \\
- Inseminasi & 100.000 & 100.000 \\
- Lain-lain & 125.000 & 185.000 \\
Biaya implisit & 1.520 .000 & 2.580 .000 \\
- Tenaga kerja keluarga & 1.520 .000 & 2.280 .000 \\
- Bekatul & - & 250.000 \\
- Pupuk Kandang & - & 50.000 \\
\hline HASIL & $\mathbf{3 . 8 3 8 . 5 0 0}$ & $\mathbf{6 . 6 7 3 . 8 1 0}$ \\
- Gabah kering panen & 3.538 .500 & 2.873 .810 \\
- Pedet & 300.000 & 3.500 .000 \\
- Pupuk organik & $\mathbf{3 . 0 1 3 . 0 0 0}$ & 300.000 \\
\hline PENDAPATAN & $\mathbf{1 , 6 4}$ & $\mathbf{5 . 5 9 2 . 3 1 0}$ \\
\hline R/C & & $\mathbf{1 , 8 2}$ \\
\hline
\end{tabular}

\section{KESIMPULAN}

Sistem pembibitan ternak sapi potong merupakan keterpaduan dalam usahatani integrasi tanaman - ternak dalam upaya penyediaan bibit/bakalan ternak sapi potong dan pupuk organik untuk lahan pertanian. Ditinjau dari aspek penggunaan tenaga kerja keluarga dalam usahatani integrasi tanamanternak merupakan pemanfaatan waktu luang diluar usaha tanaman. Dengan kepemilikan lahan yang sempit melalui usahatani integrasi tanaman - ternak dapat meningkatkan efisiensi dan pendapatan usahatani. 


\section{DAFTAR PUSTAKA}

Balai Informasi dan Penyuluhan Pertanian Kabupaten Bantul. 2005. Rencana Kerja Penyuluhan Pertanian dan Kehutanan BPP Kecamatan Srandakan Tahun 2005. Proyek Desentralisasi Penyuluhan Pertanian dan Kehutanan (DAFEP), Bantul.

Diwyanto, K., D.M. Sitompul, Ishak Manti, I.W. Mathius dan Soentoro. 2003. Pengkajian Pengembangan Usaha Sistem Integrasi Kelapa Sawit-Sapi. Prosiding Lokakarya Nasional Sistem Integrasi Kelapa Sawit - Sapi, Bengkulu, 9 - 10 September 2003, Pusat Penelitian dan Pengembangan Peternakan, Bogor.

Haryanto, B., I. Inounu, IGM. B. Arsana dan K. Diwyanto, 2002. Panduan Teknis Sistem Integrasi Padi-Ternak. Badan Penelitian dan Pengembangan Pertanian. Departemen Pertanian. Jakarta.

Inounu, I dan D. Lubis. 2005. Sumbangan Inovasi Teknologi Peternakan Mendukung Agribisnis Untuk Peningkatan Ketahanan Pangan. Prosiding Seminar Nasional Teknologi Peternakan dan Veteriner. Bogor, 12 13 September 2005. Pusat Penelitian dan Pengembangan Peternakan, Bogor.

Musofie dan Wardhani, 2001. Integrasian Usahatani Tanaman-Ternak Dalam Kegiatan Agribisnis di Daerah Istimewa Yogyakarta. Prosiding Seminar Nasional Terknologi Spesifik Lokasi. Balai Pengkajian Teknologi Pertanian Yogyakarta.

Supriadi dan Soeharsono. 2003. Studi Potensi Hijauan Pakan Ternak di Kawasan "Wedi Kengser" Sungai Progo Daerah istimewa Yogyakarta. Prosiding Seminar Nasional Penerapan Teknologi Tepat Guna dalam Mendukung Agribisnis.

Yogyakarta, 24 September 2003. Pusat Penelitian dan Pengembangan Sosial Ekonomi Pertanian. Balai Pengkajian Teknoogi Pertanian (BPTP) Yogyakarta bekerjasama dengan Institu Pertanian "STIPER" Yogyakarta.

Wiyono, D. B dan Mariyono. 2005. Review Hasil Penelitian Model Low External Input di Loka Penelitian Sapi Potong tahun 2002-2004. Prosiding Seminar Nasional Teknologi Peternakan dan Veteriner. Bogor, 12 - 13 September 2005. Pusat Penelitian dan Pengembangan Peternakan, Bogor. 